\title{
Dinamika pengelolaan wakaf uang: studi sosio-legal perilaku pengelolaan wakaf uang pasca pemberlakuan UU No. 41 tahun 2004 tentang wakaf
}

\author{
Hasbulah Hilmi \\ STAI Darul Lugah Wadda'wah Bangil Pasuruan \\ E-mail:hasbullah.bilmi@gmail.com
}

The reality of the implementation of cash waqf after regulation Act No. 41 in 2004 on Waqf studied to address the problem: how cash waqf be understood accepted and implemented by the cash waqf institutions; and how cash waqf be managed by cash waqf institutions in Indonesia? The study is a socio-legal study with phenomenological qualitative research methods. This study focus on understanding the cash waqf regulation as "law in the book" and how the implementation and acceptance of cash waqf as a "law in the society". Social and law change, and behavior and effectiveness of law theories are used as a research perspective The findings of this study are as follows. Firtsly, It is founded that understanding and acceptance levels of cash waqf regulations is various. The various is acceptance and using all of cash waqf regulation, using a part and totally avoidance and ignorant the regulation. Secondly, Cash waqf regulation delegitimize the cash waqf process has been developed by the community. It is impact to avoid or ignore the regulation by most of waqf board and foundations. Some foundations avoid the regulation and switch to the model of other charitable. The others ignore the regulation and keep up with the concept of cash waqf has been understood. The avoidance and ignorant foundations earn the trust (even likely to increase) of the people. The other side the development of cash waqf management as the regulation is less encouraging. It is show that waqf act especially on cash waqf regulation is less effective.

Realitas implementasi regulasi wakaf uang pasca UU No. 41 Tahun 2004 tentang Wakaf diteliti untuk menjawab permasalahan: Bagaimana wakaf uang dipahami, diterima dan diterapkan oleh lembagalembaga pengelola wakaf uang; Bagaimana perkembangan pengelolaan wakaf uang oleh lembagalembaga pengelola wakaf setelah enam tahun diundangkan di Indonesia. Kajian sosio-legal dengan 
ljtihad, Jurnal Wacana Hukum Islam dan Kemanusiaan, Vol. 12, No. 2, Desember 2012: 123-143

metode penelitian kualitatif fenomenologis dipilih penelitian ini. Regulasi wakaf uang sebagai materi "law in Book" dalam UU Wakaf dan regulasi pendukung lainnya diteliti pada tingkat penerapan dan penerimaan stakeholder pengelola wakaf uang sebagai "law in society”. Perspektif yang digunakan adalah teori perubahan hukum dan perubahan sosial, teori perilaku dan efektifitas hukum. Temuan penelitian ini adalah: Pertama, terdapat pemahaman dan tingkat penerimaan regulasi yang berbeda dalam pengelolaan wakaf uang oleh sembilan lembaga pengelola wakaf uang yang diteliti. Kedua, kecenderungan perkembangan pengelolaan wakaf uang berbeda. Wakaf uang sesuai desain UU kurang mendapat sambutan dari masyarakat. Wakaf uang yang dipahami sebagai antara untuk diwujudkan menjadi aset wakaf sosial atau produktif berkembang di masyarakat dengan pesat.

Keywords: Cash waqf; Behavior and effectiveness of the Law; Law as social engineering theory; Socialjustice philanthropy

\section{Pendahuluan}

Wakaf merupakan salah satu al-'ibädah al-mäliyah. Tidak seperti zakat, infaq, dan sedekah, keberadaan wakaf sebagai al-ibädah al-mäliyah tidak terdapat secara eksplisit di dalam AlQur'an. Penggalian hukum wakaf dilakukan ulama dengan mengelaborasi pesan-pesan implisit dalam Al-Qur'an dan bersandar pada teks-teks hadis Rasulullah saw. Teks-teks hadis terkait hukum wakaf menurut al-Zarqa (t.th.: 19) merupakan hukum ijmali dan umum. Adapun rincian hukum wakaf sebagaimana terdapat dalam kajian fikih semuanya merupakan hasil ijtihad. Dengan posisi hukum wakaf yang tidak setegas zakat, sedekah dan infaq, institusi wakaf berkembang secara kuat dalam pembahasan hukum dan budaya masyarakat Islam. Menurut Hoekter (2003: 145), dari berbagai bentuk filantropi Islam yakni zakat, sedekah, dan wakaf, hanya wakaf yang berkembang menjadi institusi-institusi hukum yang berkembang secara penuh.

Institusi wakaf berkembang secara mapan dan memberikan kontribusi besar terhadap perkembangan Islam dalam menopang lembaga-lembaga pendidikan Islam atau madrasah. Peran menonjol wakaf dapat dilihat pada berbagai sarana pendidikan Islam di Mekah dan Madinah yang dibiayai oleh dana wakaf (Najib, 2006: 1). Oleh karena itu, studi-studi perkembangan lembaga pendidikan Islam tidak akan lepas dari studi atas perkembangan institusi wakaf (Makdisi, 1981:35).

Penataan manajemen dan pengelolaan wakaf diatur dalam Undang-undang No. 41 Tahun 2004 tentang Wakaf (selanjutnya disingkat UU Wakaf) dan Peraturan Pemerintah 
No. 42 Tahun 2006 tentang pelaksana UU Wakaf (selanjutnya disingkat PP Wakaf). Undangundang ini mempunyai semangat pada penataan manajemen dan pengelolaan wakaf sehingga mencapai hasil yang maksimum yang kemudian dikenal dengan istilah wakaf produktif. Wakaf produktif didefinisikan oleh Mubarak (2008: 16) sebagai proses pengelolaan benda wakaf untuk menghasilkan barang dan jasa yang maksimum dengan modal yang minimum.

Wakaf uang merupakan salah satu bentuk inovasi wakaf yang memungkinkan pengelolaan wakaf lebih fleksibel. Model wakaf ini memberi kemungkinan partisipasi umat Islam dalam berderma lebih luas. Wakaf Uang lebih fleksibel karena obyeknya berupa benda bergerak dan juga simbolik yang memungkinkan investasi dan pemanfaatan secara lebih beragam. Tingkat partisipasi masyarakat dengan demikian diharapkan akan lebih besar karena nominal wakaf uang bisa dipecah dalam pecahan-pecahan kecil yang dapat terjangkau oleh semua kalangan. Kehadiran wakaf uang memungkinkan wakaf menjadi instrumen derma bagi semua kalangan. Wakaf uang tidak hanya bagi orang kaya tetapi juga bagi kalangan yang secara ekonomi tidak terlalu mapan.

Perkembangan pengelolaan wakaf tidak berkembang sebagaimana yang diharapkan. Pengelolaan wakaf terkesan berjalan di tempat. Lambannya perkembangan (bahkan ada indikasi mundur di beberapa lembaga), terjadi baik yang dikelola oleh Badan Wakaf Indonesia (selanjutnya disingkat BWI), Laznas atau wakaf yang dikelola oleh lembaga khusus pengelola wakaf. Keberadaan lembaga pengelola khusus wakaf uang di Indonesia masih sedikit diantaranya TWI, Water dan Yayasan Wakaf Bangun Nurani Bangsa (selanjutnya disingkat YWBNB). Jumlah lembaga pengelola wakaf uang yang sedikit, secara tidak langsung, mencerminkan perkembangan wakaf uang belum menggembirakan dan jauh dari potensi wakaf uang yang terdapat di masyarakat Indonesia.

Kehadiran UU Wakaf dan fatwa MUI ternyata belum menjadi stimulus kuat terhadap pengembangan gerakan wakaf uang di Indonesia. Kondisi ini menjadi dasar asumsi bahwa kehadiran UU Wakaf dan regulasi-regulasi di bawahnya tidak mencerminkan kesadaran hukum wakaf uang sesungguhnya di kalangan stakeholder wakaf. Secara lebih jauh diasumsikan kehadiran wakaf uang hanyalah sebuah proses legislasi top down yang tidak mencerminkan kesadaran hukum di masyarakat sesungguhnya, sehingga realisasi bentuk ideal wakaf uang hanya bersifat utopis. 
ljtihad, Jurnal Wacana Hukum Islam dan Kemanusiaan, Vol. 12, No. 2, Desember 2012: 123-143

Realitas implementasi regulasi wakaf uang pasca UU Wakaf diteliti untuk menjawab permasalahan: Bagaimana wakaf uang dipahami, diterima dan diterapkan oleh lembagalembaga pengelola wakaf uang; Bagaimana kecendrungan perkembangan pengelolaan wakaf uang oleh lembaga-lembaga pengelola wakaf setelah enam tahun UU Wakaf ditetapkan di Indonesia?

Atas dasar permasalahan di atas maka penelitian ini bertujuan: Memaparkan secara kritis realitas pemahaman dan penerapan wakaf uang di Indonesia pasca undang-undang wakaf oleh lembaga-lembaga pengelola wakaf uang; Memaparkan kecendrungan perkembangan pengelolaan wakaf uang oleh lembaga-lembaga pengelola wakaf uang di Indonesia.

\section{Metode penelitian}

Pendekatan sosio-legal dipilih sebagai model penelitian ini. Studi sosio-legal, menurut Irianto (2009: 177), diidentifikasi melalui dua hal. Pertama, kajian sosio-legal melakukan kajian tekstual terhadap peraturan perundang-undangan dan kebijakan secara kritis untuk menjelaskan problematika filosofis, sosiologis dan yuridis dari hukum tertulis. Dengan demikian diketahui apa makna dan bagaimana implikasinya terhadap subyek hukum. Kedua, kajian sosio-legal menggunakan berbagai metode baru hasil perkawinan antara metode penelitian hukum dengan penelitian ilmu sosial, seperti penelitian kualitatif sosio-legal dan etnografi sosiolegal. Penggunaan metode interdisipliner tersebut dapat menjelaskan fenomena hukum yang sangat luas seperti relasi kekuasaan dalam konteks sosial, budaya, dan ekonomi di tempat hukum berada.

Metode penelitian ilmu sosial yang digunakan adalah penelitian kualitatif dengan pendekatan fenomenologis. Penelitian ini mencoba memberikan deskripsi pada realitas wakaf uang di Indonesia dengan perspektif fenomenologis. Dengan prespektif fenomenologis bertolak tidak atas dasar normatifitas dan atau atas apa seharusnya (das sein) dari pelaksanaan wakaf uang di Indonesia. Penelitian berangkat dari posisi peneliti yang memberikan ruang pada subyek penelitian dan atau informan untuk memberikan deskripsi wakaf uang dalam presfektif masing-masing. Kerangka teoretis yang dimiliki oleh peneliti hanya bersifat pengantar untuk penajaman dan pendalaman dalam proses penggalian data dari subyek penelitian. 
Unit analisis dalam penelitian ini adalah lembaga pengelola wakaf uang berskala nasional atau yang bisa diakses secara online sebagai stakeholder wakaf uang. Subyek penelitian dan informan dipilih secara purposive dengan ditentukan sembilan informan dari sembilan lembaga yakni: Suhadji Lestiadi (Direktur Pemberdayaan Wakaf BWI), Veldi V. Armita (Direktur TWI 2009 -2010), Yahya Hidayatullah SEI (Ketua Dewan Pengurus Wakaf Center kemudian disingkat Water), Sahabuddin (Ketua Program) dan Suharsono (Pengelola) PKPU Pusat, Ade (Ketua Program) Baitul Mal Hidayatullah (kemudian disingkat BMH) Pusat, Gufron Sumaryono (Ketua) Yayasan Wakaf Bangun Nurani Bangsa (kemudian disngkat YWBNB), Tarmidzi (Direktur) Program Penghapal Al-Qur'an - Darul Qur'an (Selanjutnya disingkat PPA-Daqu), Agus Khalifatullah Shadiq (Ketua Divisi Pemberdayaan BMM), dan Zaim Saidi (Ketua Yayasan) Baitul Mal Nusantara (kemudian disingkat BMN).

Informasi yang digali dari informan secara garis besar terdiri dari profil lembaga yang dikelola, pemahaman lembaga terhadap konsep wakaf uang, pemahaman dan penerapan regulasi wakaf uang, pengelolaan wakaf uang terdiri dari penggalangan dana, investasi dan pemanfaatan hasil investasi wakaf uang, komitmen lembaga dalam investasi dan pemanfaatan hasil wakaf untuk keadilan sosial.

Pengumpulan data diawali dengan pengumpulan data sekunder. Peneliti mengumpulkan data terkait dengan subyek penelitian dari sumber online yang diampu subyek penelitian dan dari penelitian-penelitian terdahulu terkait subyek penelitian.Pengumpulan data primer dilakukan dengan wawancara mendalam.

Analisis data dalam penelitian kualitatif sudah mulai berjalan seiring dengan proses penelitian berlangsung. Secara rinci proses analisis dilakukan dalam tiga tahapan yakni reduksi data, model data (data display) dan penarikan kesimpulan.

\section{Wakaf, wakaf uang dan regulasi wakaf uang}

Pengertian wakaf dan wakaf produktif

Istilah wakaf menurut Zarqa (1947: 13) pada awalnya dinamai sadaqah, habas dan habisan baru kemudian nama wakaf dan nama ini kemudian yang menjadi mashur. Sampai sekarang istilah abbās masih dipakai di negara Magrib. 
Istilah sedekah jariah bersumber dari hadis riwayat Imam Turmudzi (al-Ula, t.th.: Juz 4, 522) yang berbunyi:

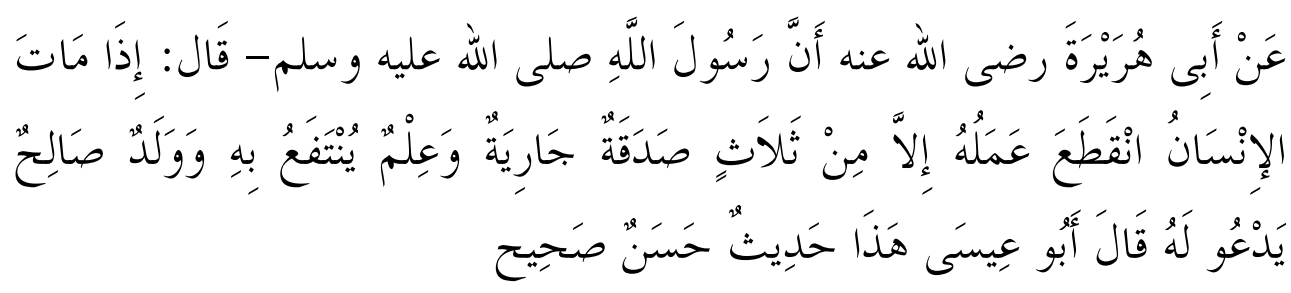

Hadis di atas menggunakan istilah sedekah jariah. Pemahaman hadis ini menunjukkan sedekah terbagi dua. Yakni sedekah yang bersifat langsung habis asal dan manfaatnya. Dan sedekah yang asalnya tetap dan manfaatnya yang mengalir terus. Model kedua dinamakan sedekah jariyah.

Istilah wakaf secara bahasa berasal dari waqafa, al-wuqūf yang berarti lawan kata al-julüs. Waqafa al-ard artinya habasaha (Ibn Manzur, t.th.: Juz 6, 4898). Kalimat waqafahā al-dār artinya ia menahan rumahnya untuk di jalan Allah. Bentuk fä 'il-nya wäqif. Wäqif menurut istilah fuqahä, adalah orang yang mewakafkan hartanya di jalan Allah. Bentuk thulathi mazidnya adalah awqafa yang berarti menjadikanya wakaf, seperti kalimat awqafa al-dār artinya menjadikan rumahnya wakaf di jalan Allah (Ma'luf dan Tottel, 1986: 914) tetapi kata awqafa tidak diterima oleh kalangan ulama bahkan sebagaian ulama mengingkari keberadaannnya secara bahasa. Kata waqfun sering dipergunakan dalam artian maf'u l seperti " ha dha al-bayt waqfun" artinya rumah ini diwakafkan (Basya, 2006: 77). Istilah ini yang umum digunakan oleh para ulama.

Pengunaan istilah ḅubus diantaranya adalah Imam al-Syafi'i (t.th.: jilid 3, 51) dalam alUmm dengan istilah al-ạ̣bas. Di kalangan Mazhab Maliki di Magribi Aljazair, dan Tunisia, wakaf disebut ḅubus ( bentuk jamak dari ḥabis) dan dalam bentuk lain ia juga dikenal dengan nama ḥubs (kata jamak ạ̣bas). Orang-orang Perancis telah menerima perkataan hobous dalam bahasa resmi mereka (Othman, 2010: 57) Adanya perbedaan nomenklatur wakaf mencerminkan bahwasanya wakaf merupakan sebuah instrument keagamaan ijtihadi. Bahkan Ibrahim Bek (2009: 12) menegaskan bahwa seluruh hukum-hukum tentang wakaf adalah ijtihadiyah.

Pendefinisian wakaf di kalangan ulama sangat beragam. Keragaman tersebut terletak pada penempatan syarat wakaf yang diikhtilafkan dalam definisi wakaf. Dari keragaman 
tersebut Qohaf (2006: 62) memberikan alternatif pengertian wakaf sebagai berikut:

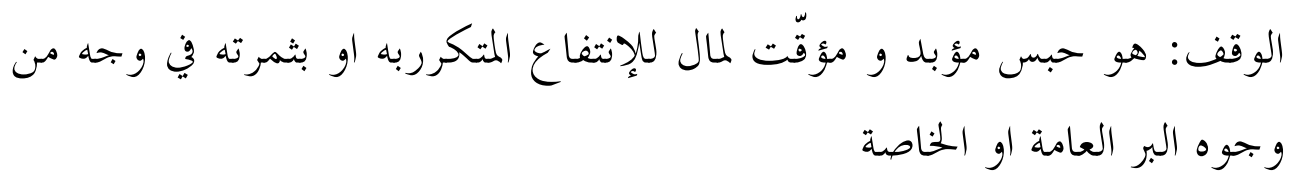

Pengertian Qohaf ini menjelaskan wakaf dibagi pada dua bagian yakni : Pertama, wakaf langsung yakni wakaf yang pokok barangnya langsung digunakan untuk mencapai tujuan wakaf, seperti masjid untuk shalat, sekolah untuk kegiatan belajar mengajar dan rumah sakit untuk mengobati orang sakit. Kedua, wakaf produktif yakni wakaf yang pokok barangnya digunakan untuk kegiatan produksi dan hasilnya diberikan sesuai tujuan wakaf (Qohaf, 2006: 62).

Wakaf uang adalah wakaf berupa uang tunai yang diinvestasikan ke dalam sektor-sektor ekonomi yang menguntungkan dengan ketentuan prosentase tertentu digunakan untuk pelayanan sosial (Abubakar, 2006: 78). Secara lebih khusus, pengertian wakaf uang dalam konteks regulasi di Indonesia adalah wakaf berupa harta benda bergerak uang (UU No. 41/2004 tentang wakaf Pasal 16 Ayat 3) dengan mata uang rupiah (PP no 42/2006 tetang wakaf Pasal 22 Ayat 1) melalui lembaga keuangan syariah yang ditunjuk pemerintah (UU Wakaf Pasal 28) yang mengeluarkan SWU (UU Wakaf Pasal 29). Dengan pengelolaan dan pengembangan harta wakaf uang hanya dapat melalui investasi pada produk-produk LKS dan atau instrumen keuangan syariah (PP Wakaf Pasal 8 Ayat 2) yang mendapat jaminan keutuhannya oleh lembaga Penjamin Simpanan (PP Wakaf Pasal 8 Ayat 4) atau Lembaga Asuransi Syariah (PP Wakaf Pasal 8 Ayat 5).

\section{Pandangan ulama tentang wak af uang}

Terdapat perbedaan pendapat di kalangan ulama mengenai keabsahan wakaf uang. Perbedaan pendapat terdapat tidak hanya perbedaan antar mazhab tetapi juga terdapat perbedaan dalam satu mazhab.

Abu Hanifah termasuk yang menolak keberadaan wakaf secara otomatis tidak menerima pula keberadaan wakaf uang. Mazhab Hanafi yang menerima keabsahan keberadaan wakaf uang adalah Ibnu Abidin. Ibnu Abidin (2003: 6/555) berpendapat soal sah tidaknya wakaf uang tergantung adat kebiasaan di satu tempat. Wakaf dinar dan dirham sudah menjadi 
kebiasaan di negeri Romawi sehingga dengan dasar prinsip di atas wakaf dinar dan dirham sah di tempat itu dan tidak sah ditempat lainnya.

Malik bin Anas dalam kitab Mudawwanah (al-Tanukhi, 1994: 4/419) membolehkan wakaf benda bergerak dan wakaf muaqqat, atas dasar kebolehan wakaf benda bergerak dan wakaf muaqqat maka dalam prespektim Malik bin Anas tidak ada masalah dengan wakaf dinar dan dirham. Kebolehan wakaf uang dalam pandangan Malik tercermin secara tersirat dari jawaban Malik yang mengharuskan adanya Zakat bagi orang yang mewakafkan dinar dan dirham yang diinvestasikan dalam pedagangan. Al-Dasyuqi menjelaskan kedudukan wakaf benda bergerak di dalam mazhab Maliki dibolehkan dan membolehkan wakaf benda sekali pakai seperti pakaian. Wakaf benda sekali pakai habis seperti makanan makruh.

Al-Nawawi (t.th.:15/325), mazhab Syafi'i, berpendapat bahwa ulama berbeda pendapat tentang keabsahan wakaf dinar dan dirham. Bagi yang berpendapat dinar dan dirham dapat memberikan keuntungan seperti ijarah maka wakaf dinar dan dirham dibolehkan. Apabila berpendapat tidak boleh ijarah maka tidak boleh pula wakaf dinar dan dirham. Wakaf dinar dan dirham dibolehkan bila dinar dan dirham digunakan untuk perhiasan.

Ibn Qudamah, mazhab Hanbali, dalam kitabnya al-Mughni (t.th.: 6/235) meriwayatkan bahwa sebagian besar ulama tidak membolehkan wakaf uang dinar dan dirham dengan alasan dirham dan dinar akan lenyap ketika dibayarkan sehingga tidak ada wujudnya. Ibn Qudamah juga menjelaskan alasan tidak sahnya wakaf uang dengan mempersewakan uang maka telah merubah fungsi utama uang sebagai alat tukar sama halnya dengan larangan mewakafkan pohon untuk jemuran oleh karena fungsi utama pohon bukan untuk jemuran pakaian.

Kebolehan wakaf uang di Indonesia telah diputuskan melalui fatwa tentang kebolehan wakaf uang oleh MUI (MUI, 2003: 86). Konsideran putusan fatwa MUI menggambarkan bahwa definisi wakaf yang dipahami mayoritas masyarakat Indonesia yang bersumber pada kitab-kitab mazhab Syafi'i dan Kompilasi Hukum Islam menimbulkan kesimpulan hukum tidak sahnya wakaf tunai. Pada sisi lain Komisi fatwa mempertimbangkan posisi wakaf uang yang memiliki fleksibilitas dan kemaslahatan besar yang tidak dimiliki oleh benda lain (MUI, 2003: 80). Konsideran "memperhatikan” dalam komisi fatwa mempertimbangkan pendapat Imam Zuhri, Mutaqaddimin ulama mazhab Hanafi dan sebagian ulama Mazhab 
Syafi'i memfatwakan bolehnya wakaf dinar dan dirham (MUI, 2003: 81).

Titik pangkal perbedaan kebolehan wakaf uang adalah pemahaman tentang keabadian uang sebagai media wakaf sekaligus kebolehan adanya wakaf temporer. Dalam menyikapi perbedaan tersebut Hendra (2008: 28 - 29) cenderung pada pendapat yang membolehkan dengan alasan pada tujuan umum wakaf untuk memberikan manfaat pahala atas benda yang diwakafkan secara terus menerus itu terealisir dalam wakaf uang. Walaupun fisiknya lenyap setelah di-tasarruf-kan tetapi nilainya tetap dan manfaatnya tetap mengalir. Alasan kedua wakaf merupakan konsep fikih ijtihadiyah sehingga memberi peluang pintu ijtihad yang lebar. Terlebih Wakaf masuk kategori fikih muamalat dengan kaidah hukum asal dalam muamalah itu adalah sah sampai ada dalil yang menyatakannya tidak sah.

\section{Regulasi wakeaf uang di Indonesia}

Wakaf uang merupakan fenomena baru di Indonesia. Model wakaf uang atau lebih dikenal dengan istilah wakaf tunai baru muncul pengaturannya dalam UU Wakaf. Sebelum UU Wakaf lahir belum ada pengaturan atau regulasi terkait dengan wakaf uang, pengaturan wakaf lebih tertuju pada pengaturan wakaf harta tidak bergerak khususnya tanah.

Regulasi terkait dengan wakaf uang adalah: Pertama, UU No. 41 Tahun 2004 tentang Wakaf. Pasal 1 Ayat 5 mendefinisikan benda wakaf tidak hanya mencakup benda tidak bergerak dan benda bergerak secara konvensional tetapi juga mencakup benda ekonomi modern seperti surat berharga dan hak karya intelektual. Dengan pendefinisian benda wakaf seperti ini maka uang dapat dikategorikan sebagai benda wakaf karena memiliki daya tahan lama dan nilai ekonomi. Penegasan uang sebagai benda wakaf terdapat dalam bagian keenam tentang harta benda wakaf pasal 1 tentang harta benda bergerak. Pengaturan khusus wakaf uang terdapat dalam bagian kesepuluh yang membahas wakaf benda bergerak berupa uang. Pelaksanan wakaf uang dilakukan melalui lembaga keuangan syariah (LKS) yang ditunjuk menteri. Pernyataan kehendak wakaf uang dilakukan secara tertulis dalam bentuk sertifikat wakaf yang dibuat oleh lembaga keuangan syariah di mana wakaf uang itu dilakukan. LKS mempunyai kewajiban melaporkan wakaf uang ke menteri.

Kedua, Peraturan Pelaksana Pemerintah Nomor 42 Tahun 2006 tentang Pelaksanaan UU No. 41 Tahun 2004 tentang Wakaf. Peraturan khusus terkait pengelolaan wakaf uang terdapat 
ljtihad, Jurnal Wacana Hukum Islam dan Kemanusiaan, Vol. 12, No. 2, Desember 2012: 123-143

pada paragraf 3 mengenai benda bergerak berupa uang. Paragraf ini terdiri dari 6 Pasal. Pasal 22 Ayat 1 dan 2 mengatur tentang keharusan wakaf uang dengan mata uang rupiah dan kewajiban mengkonversi ke mata uang rupiah bila asalnya dari mata uang non rupiah. Ayat 3 dan 4 Pasal ini mengariskan kewajiban wakif dalam proses mewakafkan wakaf uang. Pasal 23 - 25 mengatur tentang lembaga keuangan syariah pengelola wakaf uang atau disingkat LKS-PWU. Pasal 26 mengatur tentang sertifikat wakaf uang (SWU). Pasal 27 mengatur ketentuan wakaf temporer dalam wakaf uang. Pengaturan khusus wakaf uang lain terdapat dalam bagian ketiga tentang Pejabat Pembuat Akta Ikrar Wakaf (PPAIW) Pasal 37 Ayat 3 yang menggariskan PPAIW khusus wakaf uang adalah pejabat Lembaga Keuangan Syariah (LKS) setingkat kepala Seksi. Ayat 4 dan 5 mengatur kemungkinan notaris sebagai PPAIW termasuk untuk wakaf uang. Pengaturan yang terkait dengan investasi wakaf uang dalam Peraturan Pemerintah Nomor 42 tahun 2006 tersebar dalam beberapa Pasal dan Ayat. Pasal 23 menegaskan bahwa wakif dapat mewakafkan benda bergerak berupa uang harus melalui LKS yang ditunjuk oleh Menteri sebagai LKS Penerima Wakaf Uang (LKS-PWU). Pasal 25 poin c dan d menegaskan posisi lembaga keuangan syariah bukan sebagai nazhir wakaf uang tapi hanya perantara dan keharusan menempatkan dana wakaf ini dalam rekening wadiah atas nama nazhir. Pasal 48 Ayat 1 memberi kewenangan kepada BWI untuk membuat peraturan yang wajib dijadikan pedoman dalam pengelolaan wakaf uang. Dalam Ayat 2-3 dan 4 ditegaskan investasi wakaf uang hanya dapat dilakukan melaui produk-produk LKS dan atau instrumen keuangan syariah. Investasi di perbankan syariah harus masuk dalam program penjaminan LPS adapun investasi di luar perbankan harus diasuransikan dalam asuransi syariah.

Ketiga. Peraturan BWI Nomor 01 Tahun 2009 Tentang Pedoman Pengelolaan dan Pengembangan Harta Benda Wakaf Bergerak Berupa Uang. Keempat, Peraturan Menteri Agama (PMA) Nomor 4 Tahun 2008 tentang Administrasi Pendaftaran Wakaf Uang.

\section{Perkembangan wakaf uang}

Terdapat perbedaan perkembangan antara lembaga yang menerapkan model desain wakaf sesuai undang-undang dengan lembaga yang mengembangkan model wakaf uang atau wakaf tunai sebagaimana yang dipresepsikan masyarakat. BWI, Water dan BMM termasuk 
lembaga yang mengembangkan model wakaf uang yang sesuai dengan perundang-undangan. Ketiga lembaga ini mengembangkan model wakaf uang dalam artian benda wakaf yang dijaga keutuhannya adalah nominal uang wakaf dan menggunakan instrumen LKS dalam proses penggalangan dan investasinya.

Program wakaf uang BWI, dan Water serta program wakaf tunai BMM mempunyai kekhasan kelembagaan yang secara tidak langsung berpengaruh pada pola pengelolaan. BWI merupakan pengelola wakaf uang yang legalitasnya ditetapkan oleh UU, dan berperan sebagai regulator sekaligus pengelola wakaf uang bertaraf nasional. BMM merupkan pengelola wakaf uang yang dilahirkan dan terikat secara emosional dengan Bank Muamalat sebagai bank syariah pertama di Indonesia dan termasuk LKS-PWU. Water adalah pengelola wakaf uang independen yang tidak punya kaitan langsung dengan lembaga perbankan syariah dan regulator wakaf uang.

Dengan variasi karakteristik lembaga serta pola pengelolaan wakaf uang yang beragam secara kualitatif ditemukan trend perkembangan yang kurang menggembirakan. Perkembangan pengelolaan cenderung menurun peforma seperti dari program Wakqtumu Bank Muamalat. Perkembangan tidak seimbang dengan kapasitas lambang seperti wakaf uang BWI. Perjalanan kelembagaan belum beranjak dari lembaga yang kecil dan pinggiran seperti lembaga Water.

Pemahaman masyarakat secara luas terhadap institusi wakaf, mayoritas masih memahami wakaf itu tanah pekuburan dan masjid. Dengan pandangan ini maka kemunculan fatwa MUI yang menghalalkan wakaf uang menjadi pemahaman yang mendukung pandangan dasar wakaf sebagai sarana sosial. Wakaf uang diartikan sebagai wakaf dengan uang tunai sebagai media pengumpulan dan transaksi wakaf yang kemudian dialihkan untuk dana pembelian dan pembangunan sarana sosial. Lembaga yang mengapresiasi animo dan pemahaman masyarakat terahadap model wakaf uang untuk dijadikan antara aset sosial secara aktif melakukan pengalangan dan pengelolaan wakaf tunai seperti yang dilakukan BMH dan PPPA-Daqu. Lembaga yang secara pelan merubah paradigma wakaf menjadi paradigma wakaf produktif secara pelan meningalkan model wakaf ini sebagaimana yang dilakukan oleh TWI. Dan lembaga yang secara hukum memahami bahwa model wakaf tunai antara untuk aset sosial bukan dalam artian sebagaimana digariskan oleh regulasi wakaf 
ljtihad, Jurnal Wacana Hukum Islam dan Kemanusiaan, Vol. 12, No. 2, Desember 2012: 123-143

uang di Indonesia secara bertahap surut seperti PKPU yang meninggalkan model wakaf tunai untuk mobil jenazah.

Lembaga yang secara konsisten masih mengembangkan model wakaf tunai untuk pembangunan sarana pendididkan dan sosial yang diteliti adalah BMH dan PPPA-Daqu. Dengan pemahaman dan model yang berbeda dengan pemahaman wakaf uang versi BWI (Negara dan regulasiwakaf uang) pengelolaan wakaf tunai oleh BMH dan PPPA-Daqu mendapat kepercayaan masyarakat yang sangat besar.

Model wakaf uang lain adalah wakaf uang sebagai antara untuk dialihkan menjadi aset produktif. Model ini sejalan dengan semangat UU Wakaf yakni wakaf itu harus bersifat produktif. Model pengalihan wakaf uang menjadi aset produktif dikembangkan secara beragam oleh empat lembaga berbeda sebagai berikut: 1) Pengalihan wakaf uang menjadi saham oleh YWBNB; 2) Pengalihan Wakaf uang menjadi aset properti dan modal usaha produktif oleh TWI; 3) Pengalihan sedekah produktif menjadi modal usaha perikanan dan peternakan hewan qurban oleh PPPA-Daqu; 4) Pengalihan Wakaf tunai untuk modal bergulir dengan akad qordlul hasanah dan untuk pembangunan imaret oleh BMN.

Keragaman orientasi dan model pengalihan wakaf uang/tunai menjadi aset produktif mengalami perkembangan dan kemajuan yang berbeda dari tiga lembaga yang diteliti.

\section{Perilaku dan efektifitas hukum pengelolaan wakaf uang}

Kalangan positivis secara sistematis mengeliminasi perilaku sebagai bagian penting dari hukum dan mengatakan hukum itu suatu sistem yang rasional. Kalangan positivis memandang hukum itu sebagai suatu keteraturan. Tesis ini dibantah oleh Shamford (1989:20-21) yang menolak pandangan hukum itu sebagai sistem yang sistematik, ia menegaskan banyaknya ketidak teraturan, ketidakcocokkan antara teks dan perilaku mereka yang mengoperasikan teks tersebut. Oleh karena itu, dalam bahasa Shamford, hukum itu bukan semata-mata peraturan melainkan lebih merupakan interaksi dari kekuatan. Pernyataan ini didukung Rahardjo (2009c: x) yang menegaskan hukum itu bukan hanya peraturan tetapi juga perilaku. Secara lebih ekstrim Rahardjo menegaskan tesisnya bahwasanya fundamental hukum tidak terletak pada bahan hukum (legal stuff), sistem hukum, berpikir hukum, dan sebagainya melainkan lebih pada manusia atau perilaku manusia 
Kajian perilaku hukum merupakan kritik atas model kajian aliran hukum positivis. Perilaku hukum (legal behavior) menjadi obyek kajian hukum sebagai kritik atas kalangan positivis yang membatasi kajian hukum pada hukum itu sendiri. Perilaku hukum sebagaimana diungkapkan Friedman (2009:2) adalah dampak peraturan, tatanan dan perintah terhadap perilaku. Perilaku hukum bisa merupakan respon langsung atas sebuah tindakan hukum bisa juga respon tidak langsung atau campuran terhadap banyak tindakan hukum.

Respon atas sebuah tindakan hukum tidak selamanya bermakna reaksi positif seperti mematuhi peraturan, menaati perintah pemegang otoritas hukum, melainkan tindakan tidak patuh atau mengabaikan sebuah tindakan hukum juga termasuk kategori perilaku hukum. Bahkan menurut Friedman (2009: 283 - 285) perilaku hukum tidak sekedar taat dan tidak taat tapi juga termasuk menggunakan "use" atau tidak mengunakan "no use" terhadap sebuah tindakan hukum. Taat dan tidak taat lebih berkonotasi pada tindakan hukum pidana sedangkan istilah "use" atau "no use" bisa secara luas pada keseluruhan tindakan hukum baik perdata maupun administratif. Friedman (2009: 108) menambahkan termasuk perilaku hukum adanya pengabaian dan pembiaran perilaku yang tidak sejalan dengan hukum.

Perilaku hukum pengelola wakaf uang pasca UU Wakaf beragam pada tingkat pemahaman dan implementasinya. Perbedaan pemahaman dan pengelolaan wakaf uang secara garis besar terbagi pada lima katagori, yaitu: 1) Pemahaman dan implementasi model wakaf uang yang diatur UU wakaf seperti yang dilakukan BWI; 2) Pemahaman dan pengelolaan wakaf uang secara garis besar sesuai dengan UU Wakaf namun dalam beberapa tindakan praktis menyalahi UU Wakaf seperti yang terjadi pada pengelolaan wakaf BMM dan Water; 3) Ketidakpahaman atau bahkan kesalahpemahaman terhadap model wakaf uang yang diatur UU Wakaf seperti dengan wakaf tunai BMH dan PPPA-Daqu dan wakaf mobil ambulan PKPU; 4) Secara pragmatis, berpaling dari pemahaman dan pengelolaan wakaf uang menurut UU Wakaf beserta produk regulasi di bawahnya ke pemahaman wakaf tunai sebagai antara untuk investasi wakaf di sektor riil. Lembaga yang mempunyai pemahaman dan model pengelolaan ini adalah TWI; 5) Model kelima wakaf uang dihindari untuk dilakukan dengan alasan substantif. Alasan penolakan wakaf uang karena uang, dalam hal ini uang kertas, adalah produk riba. Dengan pemahaman seperti ini, wakaf tunai yang dikelola BMN dalam bentuk mata uang dinar dan dirham yang dikumpulkan untuk dijadikan 
ljtihad, Jurnal Wacana Hukum Islam dan Kemanusiaan, Vol. 12, No. 2, Desember 2012: 123-143

bangunan atau benda wakaf lain.

Pada tahun 2010 BWI secara gencar melakukan sosialisasi wakaf uang terhadap masyarakat dan pengelola wakaf di Indonesia. Implikasi dari sosialisasi ini adalah efek delegimitasi yang kuat pada proyek-proyek wakaf tunai yang telah berjalan dan dianggap tidak sesuai dengan desain undang-undang.

Respon terhadap proses delegimitasi wakaf uang/tunai oleh lembaga pengelola wakaf uang berbeda-beda. Beberapa lembaga mengakui wakaf tunai yang dikelola lembaganya menyalahi desain undang-undang.

Kepatuhan dan pemakaian terhadap regulasi wakaf uang oleh sembilan lembaga pengelola wakaf uang dikategorikan sebagai sikap positif. Sebaliknya, ketidakpatuhan dan pengabaian dikatagorikan sikap negatif. Perilaku positif dan negatif sembilan lembaga pengelola wakaf uang tercermin sebagaimana bagan di bawah ini:

Tabel 1 Regulasi dan Perilaku Hukum Pengelola Wakaf Uang

\begin{tabular}{|c|c|c|c|}
\hline Katagori & $\mathbf{U U}$ & Perilaku Positif & Perilaku Negatif \\
\hline $\begin{array}{l}\text { Nomen- } \\
\text { klatur }\end{array}$ & $\begin{array}{l}\text { wakaf berupa harta } \\
\text { benda bergerak } \\
\text { uang (UU No. } \\
41 / 2004 \text { tentang } \\
\text { wakaf pasal } 16 \text { ayat } \\
\text { 3) }\end{array}$ & $\begin{array}{l}\text { Wakaf Uang: BWI } \\
\text { dan Water }\end{array}$ & $\begin{array}{l}\text { Wakaf Tunai: BMM, BMN, BMH, } \\
\text { PKPU, PPPA-Daqu, TWI dan }\end{array}$ \\
\hline $\begin{array}{l}\text { Obyek } \\
\text { Wakaf }\end{array}$ & $\begin{array}{l}\text { Wakaf Uang } \\
\text { dengan mata uang } \\
\text { rupiah (PP no } \\
42 / 2006 \text { tetang } \\
\text { wakaf pasal } 22 \text { ayat } \\
\text { 1) }\end{array}$ & $\begin{array}{l}\text { BWI, BMM dan } \\
\text { Water }\end{array}$ & $\begin{array}{l}\text { Uang sebagai antara aset sosial: } \\
\text { TWI (sebagian kecil), YWBNB } \\
\text { (sebagian ), PKPU, BMH dan PPPA } \\
\text { Daqu. } \\
\text { Uang sebagai antara aset produktif } \\
\text { lain: TWI, YWBNB, PKPU } \\
\text { (sebagian kecil), BMN. }\end{array}$ \\
\hline LKS & $\begin{array}{l}\text { Wakaf Uang } \\
\text { melalui LKS-PWU } \\
\text { (UU Wakaf pasal } \\
\text { 28) }\end{array}$ & BWI dan BMM & $\begin{array}{l}\text { Perbankan konvensional sebagai } \\
\text { media penumpulan dana: TWI, } \\
\text { PPA-Daqu, YWBNB, BMH, PKPU. } \\
\text { Digunakan LKS tidak dalam } \\
\text { kapasitas sebagai LKS-PWU:Water } \\
\text { dengan BPJakarta }\end{array}$ \\
\hline
\end{tabular}




\begin{tabular}{|c|c|c|c|}
\hline Legalitas & $\begin{array}{l}\text { Nazhir adalah } \\
\text { terdaftar di } \\
\text { Kementrian Agama } \\
\text { dan BWI (PP pasal } \\
7 \text { dan pasal 11). }\end{array}$ & BWI & $\begin{array}{l}\text { Data akhir } 2010 \text { belum ada satupun } \\
\text { nazhir Wakaf uang terdaftar di } \\
\text { BWI }\end{array}$ \\
\hline SWU & $\begin{array}{l}\text { LKS-PWU yang } \\
\text { mengeluarkan } \\
\text { SWU (UU Wakaf } \\
\text { pasal 29). }\end{array}$ & BWI & $\begin{array}{l}\text { SWU dari nazhir: TWI, Water, } \\
\text { YWBNB, BMM, PKPU. } \\
\text { Hanya di catat administratif., BMN }\end{array}$ \\
\hline $\begin{array}{l}\text { Operasio- } \\
\text { nal WU }\end{array}$ & $\begin{array}{l}\text { Operasional dari } \\
\text { hak nazhir } \\
\text { maksimal } 10 \% \text { dari } \\
\text { keuntungan invstasi }\end{array}$ & $\begin{array}{l}\text { BWI } 10 \% \\
\text { keuntungan + dari } \\
\text { pemerintah } \\
\text { Keuntungan + Dana } \\
\text { Operasional dari } \\
\text { ZIS, Water, BMM, } \\
\text { TWI, YWBNB }\end{array}$ & $\begin{array}{l}\text { Murni dana ZIS: BMH, PPPA- } \\
\text { Daqu, BMN }\end{array}$ \\
\hline investasi & $\begin{array}{l}\text { investasi pada } \\
\text { produk-produk } \\
\text { LKS dan atau } \\
\text { instrumen keuangan } \\
\text { syariah (PP Wakaf } \\
\text { Pasal } 8 \text { ayat 2) } \\
\text { mendapat jaminan } \\
\text { oleh LPS (PP } \\
\text { Wakaf pasal } 8 \text { ayat } \\
\text { 4) atau Lembaga } \\
\text { Asuransi Syariah }\end{array}$ & $\begin{array}{l}\text { Deposito dengan } \\
\text { aqad mudharabah di } \\
\text { LKS-PWU: BWI, } \\
\text { Water, BMM }\end{array}$ & $\begin{array}{l}\text { Deposito di non LKS-PWU: PKPU, } \\
\text { Water, } \\
\text { Investasi Riil tanpa lembaga } \\
\text { penjamin: BWI, YWBNB, TWI, } \\
\text { Water, PKPU } \\
\text { Investasi Sosial: TWI, BMH, } \\
\text { PPPA-Daqu, }\end{array}$ \\
\hline
\end{tabular}

Tabel di atas mencerminkan realitas pengelola wakaf uang cenderung mengabaikan atau tidak menggunakan regulasi wakaf uang dan cenderung menggunakan model dan aturan pengelolaan sendiri-sendiri. Pengabaian terhadap regulasi tidak hanya dilakukan oleh pengelola wakaf uang secara umum, pengabaian dalam hal tertentu juga dilakukan oleh BWI. BWI melakukan pengabaian regulasi investasi dengan investasi langsung dalam pendirian lembaga rumah sakit tanpa skema cost collateral sebagaimana yang terdapat dalam peraturan BWI atau tanpa lembaga penjamin secara umum sebagaimana dalam PP wakaf uang. Pengabaian oleh BWI ini diakui oleh BWI sebagai penyimpangan.

\section{Efektifitas hukum sebagai rekayasa sosial}

Fungsi hukum sebagai rekayasa sosial atau law as tool of social engineering merupakan fenomena yang menonjol pada abad XX. Gagasan fungsi hukum sebagai sarana rekayasa sosial 
ljtihad, Jurnal Wacana Hukum Islam dan Kemanusiaan, Vol. 12, No. 2, Desember 2012: 123-143

dipelopori oleh Roscoe Pound yang pada tahun 1912 menerbitkan gagasan yang kemudian dikenal sebagai aliran hukum sosiologis. Hukum dalam pandangan aliran ini tidak dilihat hanya hukum tertulis (law in the book) tetapi juga dilihat hukum sebagai proses (law in action) (Salman, 2010: 73). Pandangan dasar Pound sebagai pendasar teori hukum aliran ini memandang hukum sebagai alat proses rekayasa sosial atau law as tool of social engineering (Pound, 1954: 223).

Rekayasa sosial (social engineering) adalah cara-cara untuk memengaruhi masyarakat dengan sistem yang teratur dan direncanakan terlebih dahulu (Soekanto, 2010: 122). Kaidah-kaidah hukum sebagai alat pengubah masyarakat mempunyai peranan penting terutama dalam perubahan-perubahan yang dikehendaki atau perubahan-perubahan yang direncanakan (Soekanto, 2010: 126). Hukum sebagai rekayasa sosial menurut Rahardjo (2009: 128 -129) adalah penggunaan hukum secara sadar untuk mencapai sesuatu tertib atau keadaan masyarakat sebagaimana yang dicita-citakan atau untuk melakukan perubahan-perubahan yang diinginkan.

Regulasi wakaf uang di Indonesia terdapat dalam UU No. 41 tahun 2004 tentang wakaf, PP No. 42 Tahun 2006 tentang wakaf dan Peraturan BWI nomor 01 tahun 2009 yang mengatur khusus wakaf uang. Regulasi-regulasi tersebut mencerminkan adanya kehendak kuat dari regulator untuk menjadikan wakaf uang sebagai model derma yang dapat diterapkan dalam sistem perekonomian modern dan akuntabel. Wakaf uang diharapkan memberikan pengaruh signifikan terhadap pemberdayaan dan pengembangan masyarakat. Regulasi wakaf uang dapat dikategorikan sebagai kehendak kuat regulator dan elit penguasa dan bukan cerminan sebagai sebuah institusionalisasi perilaku dan kesadaran hukum di masyarakat. Hal ini tercermin dari perilaku pengelola wakaf uang yang mempunyai pemahaman dan perilaku pengelolaan wakaf uang yang berbeda dengan yang ditetapkan dalam regulasi.

Sebagai model derma yang dianggap baru di masyarakat dan belum muncul contoh lembaga wakaf uang yang bisa jadi panutan dan berkembang massif di masyarakat, maka kehadiran model derma wakaf uang merupakan perangkat nilai dan norma baru di masyarakat. Dengan kondisi seperti ini, lahirnya fatwa MUI tentang kehalalan wakaf uang dan UU wakaf yang membuat aturan wakaf uang dapat dipandang sebagai proses yang 
menempatkan hukum sebagai alat rekayasa sosial.

Keberhasilan proses rekayasa sosial sangat tergantung pada kemampuan hukum sebagai pelopor perubahan untuk membatasi kemungkinan disorganisasi sebagai akibat dari perubahan yang terjadi. Kemampuan untuk membatasi terjadinya disorganisasi selanjutnya tergantung pada suksesnya pelembagaan dari unsur-unsur baru yang menyebabkan terjadinya perubahan-perubahan tersebut (Soekanto, 2010: 127).

Hukum sebagai alat rekayasa sosial menurut Soekanto (2010: 132-133) dapat mencapai hasil yang positif apabila kaidah-kaidah hukum disesuaikan dengan anggapan-anggapan masyarakat. Langkah untuk rekayasa sosial menggunakan hukum harus dimulai dengan penelaahan terhadap anggapan masyarakat tentang hukum. Kemudian dilakukan telaah terhadap bagian-bagian sistem hukum yang paling dihargai oleh sebagian besar masyarakat. Setelah hukum digunakan sebagai sarana rekayasa sosial, kemudian diteliti tingkat efektifitas penerapan hukum. Penelitian efektifitas hukum dilakukan untuk mengetahui kelemahan kelemahan hukum yang diambil dari reaksi masyarakat terhadap hukum.

UU Wakaf dan regulasi-regulasi terkait wakaf uang di bawahnya mencerminkan kehendak kuat dari pihak elit, dalam hal ini legislatif dan eksekutif sebagai pembuat regulasi, untuk mengembangkan model derma wakaf uang di Indonesia. Kehendak kuat regulator harus berhadapan dengan pemahaman yang tidak sejalan tentang model derma wakaf uang yang dikembangkan oleh sebahagian masyarakat. Kondisi ini menjadikan efektifitas regulasi wakaf uang sebagai sarana rekayasa sosial di masyarakat menjadi terhambat atau bahkan tujuan regulator wakaf uang tidak tercapai sama sekali.

Efektifitas regulasi wakaf uang yang terdapat dalam UU Wakaf dan regulasi-regulasi di bawahnya sebagai sarana rekayasa sosial sangat rendah. Hal ini dibuktikan dengan tingginya perilaku negatif dalam artian perilaku hukum yang menyalahi atau mengabaikan hukum positif yang dtunjukkan oleh para pengelola wakaf uang. Tingginya kecenderungan pengabaian atau bahkan penghindaran terhadap regulasi wakaf uang yang dilakukan oleh pengelola wakaf uang mencerminkan keberadaan regulasi wakaf uang yang belum dapat diterima secara umum di masyarakat. Presepsi dan pandangan masyarakat terhadap wakaf dan wakaf uang tidak berkembang sebagaimana konsep wakaf dan wakaf uang yang didesain UU dan regulasi di bawahnya. 
ljtihad, Jurnal Wacana Hukum Islam dan Kemanusiaan, Vol. 12, No. 2, Desember 2012: 123-143

\section{Penutup}

Paparan di atas menggambarkan tentang keragaman tingkat pemahaman dan penerimaan stakeholder terhadap model wakaf uang. Keragaman ini berimplikasi pada perbedaan pola penerapan dan pengelolaan wakaf uang oleh lembaga-lembaga pengelola wakaf uang. Perbedaan pemahaman dan pengelolaan wakaf uang tersimpul pada isu-isu perbedaan nomenklatur wakaf uang dan wakaf tunai, wakaf investasi sosial dan wakaf produktif, penerimaan stakeholder pada keberadaan uang dan perbankan serta posisi lembaga keuangan syariah sebagai penerima wakaf uang, model investasi wakaf uang dan model pemanfaatan wakaf uang.

Kita juga melihat kecendrungan perkembangan yang berbeda antara model wakaf uang yang sesuai dengan desain UU Wakaf dengan model wakaf uang yang dipahami dan dikembangkang lembaga pengelola wakaf. Wakaf uang sesuai desain UU wakaf kurang mendapat sambutan dari masyarakat. Model wakaf uang yang dipahami dan berkembang di masyarakat yakni wakaf uang sebagai antara untuk diwujudkan menjadi aset wakaf sosial atau produktif berkembang dengan pesat. Perbedaan kecenderungan perkembangan membuktikan tingkat keberhasilan rekayasa sosial melalui regulasi wakaf uang rendah. Rendahnya keberhasilan karena sampai penelitian ini dilakukan pelembagaan model wakaf uang sebagaimana desain UU belum menunjukkan hasil yang signifikan dan layak dijadikan model panutan. Masyarakat justru lebih memilih model wakaf uang yang berbeda dengan desain regulasi wakaf uang yakni berupa wakaf tunai untuk dialihkan menjadi sarana sosial atau aset produktif.

Implikasi teoretis dari penelitian ini adalah membuktikan kegagalan teori hukum sebagai sarana rekayasa sosial bila terkait dengan hukum administratif dan terkait pemahaman dan keyakinan keagamaan di masyarakat. Hukum terkait dengan administratif dan keyakinan keagamaan masyarakat seharusnya hanya berperan melembagakan tertib administrasi dan tertib hukum yang berkembang di masyarakat.

Implikasi praktis dari penelitian ini adalah membuktikan bahwa model derma wakaf uang yang dikembangkan UU Wakaf dan regulasi pendukungnya kurang pragmatis dan berpihak pada keadilan sosial. Adanya keharusan investasi melalui mediasi lembaga keuangan syariah menjadikan nilai sedekah yang dihasilkan menjadi kecil dan menjadikan peran nazhir 
sebagai partner yang tidak berperan apa-apa dalam proses investasi.

Beberapa rekomendasi yang dikemukakan dari kajian ini antara lain: pertama, perlu dilakukan revisi terhadap UU wakaf dengan regulasi pendukungnya atau minimalnya melakukan tindakan pengabaian terhadap proses pengelolaan wakaf uang yang berkembang di masyarakat sesuai dengan model dan desain yang dipahami walau berbeda dan bertentangan dengan undang undang. Kedua, hal pokok yang direkomendasikan untuk dilakukan perubahan dalam regulasi wakaf uang adalah: Desain wakaf uang harus diubah dengan menjadilkan lembaga keuangan syariah sebagai nazhir langsung dengan memperketat persyaratan nazhir wakaf uang LKS harus berorientasi bisnis sosial integratif. Lembaga keuangan syariah model ini bisa berupa pendirian bank wakaf atau melalui lembaga keuangan non bank berupa koperasi jasa keuangan syariah (KJKS) atau Baitul Mal wa Tamwil (BMT); Model wakaf uang yang menjadikannya uang sebagai media antara untuk diwujudkan aset wakaf produktif merupakan model yang berkembang di masyarakat. Model ini mesti diakomodasi sebagai model wakaf uang yang dikelola oleh nazhir bukan lembaga keuangan syariah.

\section{Daftar pustaka}

Abu Zahra, Muhammad. Muḥạdarāt $\bar{i}$ al-Waqf. Beirut: Dār al Fikr al- 'Arabi, 1971.

Abubakar, dkk. Filantropi Islam \& Keadilan Sosial: Studi tentang Potensi, Tradisi, dan Pemanfaatan Filantropi Islam di Indonesia. Jakarta: CSRC UIN Jakarta, 2006.

Al-Syafi'i, Muhammad Bin Idris. al-Umm. Beirut: Dār al-Fikr, t.th.

Al-Zarqa, Mustafa Ahmad. Aḅkām al-Awqäf. Kairo: Dār'Imar, t.th.

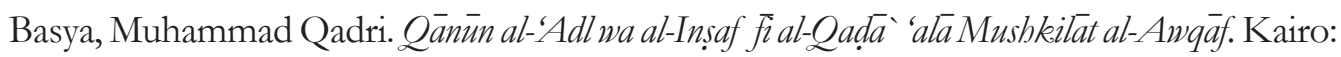
Dār al-Salām, 2006.

Black, Donald. The Behavior of Law. New York: Academic Press, 1976.

Bungin, Burhan. Penelitian Kualitatif: Komunikasi, Ekonomi, Kebijakan Publik, dan Ilmu Sosial Lainnya. Jakarta: Kencana, 2003.

Cizakca, Murat, "Awqaf in history and its implications for modern Islamic economies" dalam Islamic Economic Studies, Vol. 6 No. 1, November 1998: 43-70. 
ljtihad, Jurnal Wacana Hukum Islam dan Kemanusiaan, Vol. 12, No. 2, Desember 2012: 123-143

Friedman, Lawrence M. Sistem Hukum: PerspektifIlmu Sosial. Bandung: Nusa Media, 2009. Hasanah, Uswatun, "Wakaf dalam Peraturan Perundang-undangan di Indonesia" dalam al-Awqaf: Jurnal Wakaf dan Ekonomi Islam, Vol. 1, No. 01, Desember 2008: 9-32.

Hendra, "Wakaf Uang dalam Penanggulangan Kemiskinan di Indonesia (Studi Kasus Tabung Wakaf Indonesia dan Wakaf Uang Muamalat Baitul Mal Muamalat”, disertasi tidak diterbitkan, Jakarta: SPS UIN Jakarta, 2008.

Hoexter, Miriam, "Charity, the Poor, and Distribution of Alm in Ottoman Algier" dalam Poverty and Charity in Midle Eastern Contexts" Michael Bonner, Mine Ener and Amy Singer (eds.). New York: State University of New York, 2003.

Ibn Manzur. Lisān al-'Aarab. Kairo: Dār al Hadith, t.th.

Ibrahim Bek, Ahmad. Aḅkām al-Waqf 'alā al-Madhāhib al-Arba'ah. Kairo: Maktabah alAzhariyyah li al-Turāth, 2009.

Ibrahim, M. Anwar, "Waqf al-Nuqūd (Wakaf Uang) dalam Perspektif Hukum Islam”, AlAwqaf: Jurnal Wakaf dan Ekonomi Islam, Vol. II, Nomor 2, April 2009: 1-12.

Irianto, Sulistyowati \& Sidharta (ed.). Metode Penelitian Hukum: Konstelasi dan Refleksi. Jakarta: Yayasan Obor Indonesia, 2009.

Ma'luf, Louis dan Bernard Tottel. al-Munjid $\bar{f} i$ al-Lughah wa al-'Al'am. Beirut: Dār al-Mashriq, 1986.

Mannan, M.A. Sertifikat Wakaf Tunai: Sebuah Inovasi Instrumen Keuangan Islam. Jakarta: PKT'TIUI, 2001.

Mubarok, Jaih. Wakaf Produktif. Bandung: Simbiosa Rekatama, 2008.

Najib, Tuti A dan Ridwan al-Makassary (eds.). Wakeaf, Tuhan, dan Agenda Kemanusiaan: Studi tentang Wakaf dalam Perspektif Keadilan Sosial di Indonesia. Jakarta: CSRC UIN Syarif Hidayatullah, 2006.

Qohaf, Mundhir. Al-Waqf al Islamīi: Tatawmuruh, Idaratuh, Tanmiyatuh. Beirut: Dār al-Fikr, 2006.

Rahardjo, Satjipto. Hukum dan Masyarakat. Bandung: Angkasa, 1979. 
Rahardjo, Satjipto. Hukum dan Perubahan Sosial: Tinjauan Teoritis serta Pengalaman-pengalaman di Indonesia. Yogyakarta: Genta, 2009.

Rosalinda. Pengelolaan Wakaf Uang: Studi Kasus pada Tabung Wakaf Indonesia (TWI) Dompet Dhuafa Republika. Jakarta: UIN Syarif Hidayatullah, 2010.

Saidi, Zaim. Tidak Syar'inya Bank Syari'ah di Indonesia dan Jalan Keluarnya menuju Muamalat. Yogyakarta: Delokomotif, 2010.

Saidi, Zaim, dan Abidin, Hamid. Menjadi Bangsa Pemurah: Wacana dan Praktek Kedermawanan di Indonesia. Jakarta: Piramedia, 2004.

Salman, Otje. Filsafat Hukum: Perkembangan dan Dinamika Masalah. Bandung: Refika Aditama, 2010.

Samford, Charles DG. The Disorder of Law: A Critique of Legal Theory. Blackwell, 1989.

Soekanto, Soerjono. Pokok-pokok Sosiologi Hukum. Jakarta: Raja Grafindo Persada, 2010. 